\title{
KELIMPAHAN MEGABENTOS SEBAGAI INDIKATOR KESEHATAN KARANG DI PERAIRAN BILIK, TAMAN NASIONAL BALURAN, INDONESIA
}

\author{
Bachtiar W. Mutaqin ${ }^{1,2}$, Emy Puspita Yuendini ${ }^{1}$, Bagas Aditya ${ }^{1}$, \\ Isfi Nurafifa Rachmi ${ }^{1}$, M. Ilham Fathurrizqi ${ }^{1}$, Shinta Ira Damayanti ${ }^{1}$, \\ Sufia Nur Ahadiah ${ }^{1}$, Novanda N.A. Puspitasari ${ }^{1}$ \\ ${ }^{1}$ Departemen Geografi Lingkungan, Fakultas Geografi, Universitas Gadjah \\ Mada, Yogyakarta, Indonesia \\ ${ }^{2}$ Pusat Studi Sumberdaya dan Teknologi Kelautan, Universitas Gadjah \\ Mada, Yogyakarta, Indonesia \\ E-mail:mutaqin@ugm.ac.id
}

Received June 2020, Accepted August 2020

\begin{abstract}
ABSTRAK
Ekosistem terumbu karang adalah ekosistem laut yang sangat rentan oleh kerusakan lingkungan. Terumbu karang di perairan Bilik, Taman Nasional Baluran merupakan contoh ekosistem terumbu karang yang mengalami ancaman kerusakan lingkungan akibat perubahan iklim dan aktivitas manusia. Salah satu metode yang dapat digunakan untuk memonitor kesehatan terumbu karang adalah dengan melihat kelimpahan megabentos dalam ekosistem terumbu karang. Oleh karena itu, penelitian ini memiliki tujuan untuk mengetahui kesehatan ekosistem terumbu karang dengan melihat kelimpahan megabentos di perairan Bilik, Taman Nasional Baluran. Metode yang digunakan dalam inventarisasi megabentos adalah dengan Benthos Belt Transect dan analisis video di Blok Sijile dan Blok Jeding di Perairan Bilik. Hasil pengamatan menunjukkan bahwa di Blok Sijile tidak ditemukan ekosistem terumbu karang dan megabentos. Sementara itu di Blok Jeding ditemukan ekosistem terumbu karang dengan megabentos berupa bulu babi dan bintang laut biru. Kelimpahan bulu babi di dan bintang laut biru adalah 0-0,14 individu/m². Kondisi tersebut menunjukkan bahwa kesehatan ekosistem terumbu karang di Blok Jeding perairan Bilik Sijile masih baik, namun perlu mendapat perhatian khusus karena sebagian area terumbu karang mengalami pemutihan akibat aktivitas perikanan yang tidak ramah lingkungan.
\end{abstract}

Kata Kunci : Megabentos, Terumbu Karang, Bilik, Baluran, Situbondo

\section{ABSTRACT}

MEGABENTHOS ABUNDANCE AS CORAL HEALTH INDICATORS IN BILIK WATERS, BALURAN NATIONAL PARK, INDONESIA. Coral reef ecosystems are marine ecosystems that are prone to environmental damage. Coral reefs in Bilik waters, Baluran National Park, are examples 
of coral reef ecosystems that are threatened by environmental damage due to climate change and human activities. One of the methods for health monitoring of coral reefs is by looking at the abundance of megabenthos in coral reef ecosystems. Therefore, this study aims to determine the health of coral reef ecosystems by looking at the abundance of megabenthos in Bilik waters, Baluran National Park. We used Benthos Belt Transect and video analysis to identify the spatial distribution and number of megabenthos in Sijile Block and Jeding Block, Bilik waters. The results showed that in Sijile Block, there were no coral reef neither megabenthos ecosystems. Meanwhile, in Jeding Block, there was a coral reefs ecosystem with megabenthos in the form of sea urchins and blue starfish. The abundance of sea urchins and the blue sea star in Jeding Block was about 0-0.14 individual $/ \mathrm{m}^{2}$. These conditions indicate that the health of the coral reef ecosystem in Jeding Block, Bilik waters was still in good condition, even though it still needs special attention related to coral bleaching as a consequence of fisheries activities that are not environmentally friendly.

Keywords : Megabenthos, Coral Reef, Bilik, Baluran, Situbondo

\section{PENDAHULUAN}

Ekosistem terumbu karang adalah salah satu ekosistem yang khas di perairan tropis dengan tingkat kesuburan, keanekaragaman biota, dan nilai estetika yang tinggi tetapi termasuk salah satu yang paling peka terhadap perubahan kualitas lingkungan (Muhlis, 2011; Mutaqin dkk., 2020). Manfaat yang diberikan oleh terumbu karang sangat beragam, sehingga keberadaannya perlu dilestarikan. Di sisi lain, terumbu karang termasuk ekosistem yang sangat peka dan sensitif terhadap kerusakan. Oleh karena itu perlu upaya perlindungan dan pengelolaan lingkungan di wilayah terumbu karang dalam rangka menjaga ekosistem pesisir, ketersediaan stok ikan, dan ketahanan pangan yang berasal dari laut (Mutaqin dan Rohmah, 2013; Giyanto dkk., 2014; Mutaqin, 2017; Sunarto dkk., 2019).

Salah satu kelompok biota laut yang hidup pada ekosistem terumbu karang adalah kelompok fauna bentik. Komunitas bentik memiliki posisi yang penting sebagai mata rantai jaring makanan untuk sumber pakan bagi ikan-ikan karnivora (Lukman $d k k$., 2009). Kelompok fauna bentik memiliki ukuran yang relatif besar dengan populasi tinggi sehingga memiliki peranan penting bagi kondisi dan kestabilan ekosistem dan menjadi potensial untuk pemantauan kesehatan terumbu karang (Giyanto $d k k ., 2014)$. Kelompok fauna bentik identik dengan organisme yang menempati dasar perairan atau sering disebut sebagai bentos, yaitu seluruh organisme yang berada pada daerah yang masih dipengaruhi pasang surut air dan karakteristik hidupnya tertancap, merayap, hingga membuat lubang di dasar perairan (Sohilait, 2006). Fauna bentik yang mudah untuk diidentifikasi dan peka terhadap perubahan lingkungan perairan adalah kelompok makro fauna atau makro zoobentos. Makro 
zoobentos memiliki sebaran yang luas, ukuran yang relatif besar, serta daur hidup yang relatif lama menyebabkan organisme ini memiliki pergerakan yang relatif lambat sehingga memiliki kemampuan merespons kondisi kualitas perairan secara kontinu (Zulkifli \& Setiawan, 2012). Organisme bentik akan memperlihatkan respons terhadap pencemar yang masuk ke perairan berupa peningkatan atau penurunan kelimpahan megabentos tergantung pada jenis pencemarannya (Sohilait, 2006).

Penurunan kualitas ekosistem terumbu karang merupakan permasalahan yang sering terjadi, salah satunya dipicu oleh perubahan iklim global (Arjasakusuma $d k k$., 2020). Peningkatan suhu perairan akan berdampak pada pemutihan terumbu (coral bleaching), meningkatkan kematian terumbu, mengubah struktur komunitas, mengurangi resistensi, dan mengurangi reproduksi terumbu (Chumkiew dkk., 2011; Mutaqin dan Angga, 2013; Mutaqin $d k k$., 2018). Salah satu ekosistem terumbu karang yang terancam oleh degradasi berada di Taman Nasional Baluran.

Ekosistem terumbu karang dapat ditemukan di beberapa zona perairan yang ada di Taman Nasional Baluran, salah satunya di Perairan Bilik yang terletak di bagian sisi utara Taman Nasional Baluran (TNB) (Gambar 1). Zona intertidal di Pantai Bilik yang memiliki keanekaragaman jenis biota laut yang tinggi akibat adanya dukungan dari faktor-faktor lingkungan seperti kondisi pasang surut, komunitas lamun, populasi alga laut makro bentik, plankton, hingga banyaknya tempat perlindungan yang tersedia bagi biota laut (Nurrohmah, 2018).

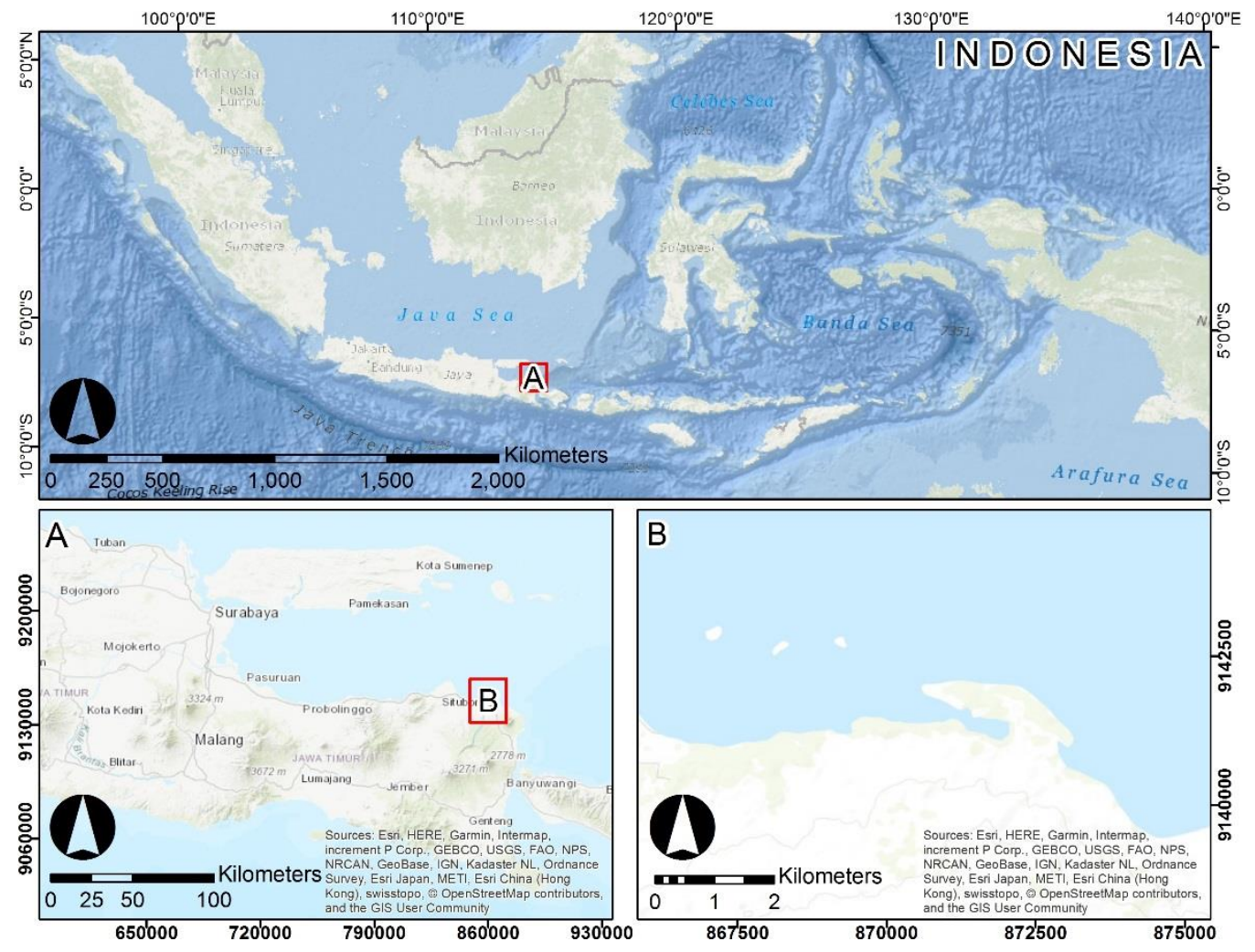

Gambar 1. Lokasi kajian di Perairan Bilik, Taman Nasional Baluran 
TNB termasuk dalam kawasan konservasi sumberdaya alam, sehingga salah satu tugas dan fungsinya adalah terkait pengelolaan ekosistem terumbu karang, sesuai dengan Peraturan Menteri Kehutanan Republik Indonesia Nomor P4/MENHUT-II/2012. Salah satu lokasi konservasi terumbu karang tersebut ada di Perairan Bilik. Meskipun termasuk dalam kawasan Taman Nasional Baluran, namun tekanan terhadap ekosistem terumbu karang tetap terjadi, seperti keberadaan penduduk sekitar yang memiliki mata pencaharian dominan sebagai nelayan, pengaruh salinitas dan evaporasi, hingga aktivitas pariwisata yang dilakukan di Pantai Bilik. Berdasarkan latar belakang tersebut, penelitian ini bertujuan untuk mengetahui kelimpahan megabentos dan kaitannya dengan kondisi terumbu karang di perairan Bilik, Taman Nasional Baluran.

\section{MATERI DAN METODE}

\section{Waktu dan Lokasi Penelitian}

Penelitian ini dilakukan pada 7-12 Oktober 2019 di Perairan Bilik yang termasuk dalam Seksi Pengelolaan Taman Nasional Baluran Wilayah II Karangtekok. Perairan Bilik berada di utara Taman Nasional Baluran yang berbatasan langsung dengan Selat Madura, memiliki kedalaman mulai dari 1 meter hingga lebih dari 40 meter. Perairan Bilik ini termasuk dalam Zona Pemanfaatan Taman Nasional Baluran yaitu pantai Bilik-Sijile (Tanjung Air Tawar sampai Tanjung Merak) dan sekitarnya. Zona pemanfaatan perairan terletak tepat bersebelahan dengan Zona Pemanfaatan Darat yang menghadap laut, melebar sampai batas terluar wilayah perairan. Total luas Zona Pemanfaatan Taman Nasional Baluran yaitu $\pm 1.856,51$ ha $(7,43 \%)$ yang mencakup daratan seluas $1.157,33$ ha dan perairan seluas 699,18 ha. Zona Pemanfaatan perairan di Seksi Pengelolaan Taman Nasional Wilayah II Karangtekok dibagi menjadi beberapa wilayah yaitu Blok Bilik, Blok Sijile, Blok Jeding (Gambar 2). Lokasi pengamatan megabentos dan terumbu karang yang dipilih dalam penelitian ini yaitu Blok Jeding dan Blok Sijile. Pemilihan lokasi penelitian ini karena daerah tersebut dapat dijangkau serta untuk membandingkan kondisi antara Blok Jeding dan Blok Sijile.

\section{Pengumpulan, Pengolahan, dan Analisis Data}

Pengamatan megabentos dilakukan dengan metode Bentos Belt Transect (BBT). BBT adalah metode yang dikembangkan dari Intersect Line Transect (ILT), yaitu dengan membuat jalur transek sejajar dengan garis pantai sepanjang 30 meter dengan lebar jalur pengamatan adalah 2 meter. Jumlah jalur transek yang dibuat adalah 9 jalur yang mencakup luas wilayah $730 \mathrm{~m}^{2}$. Pengamatan secara transek dilakukan dengan menggunakan teknik video, yaitu dengan merekam menggunakan kamera bawah air di sepanjang jalur pengamatan dan kemudian dilakukan analisis 
video untuk mengidentifikasi jenis dan jumlah megabentos di lokasi pengamatan.

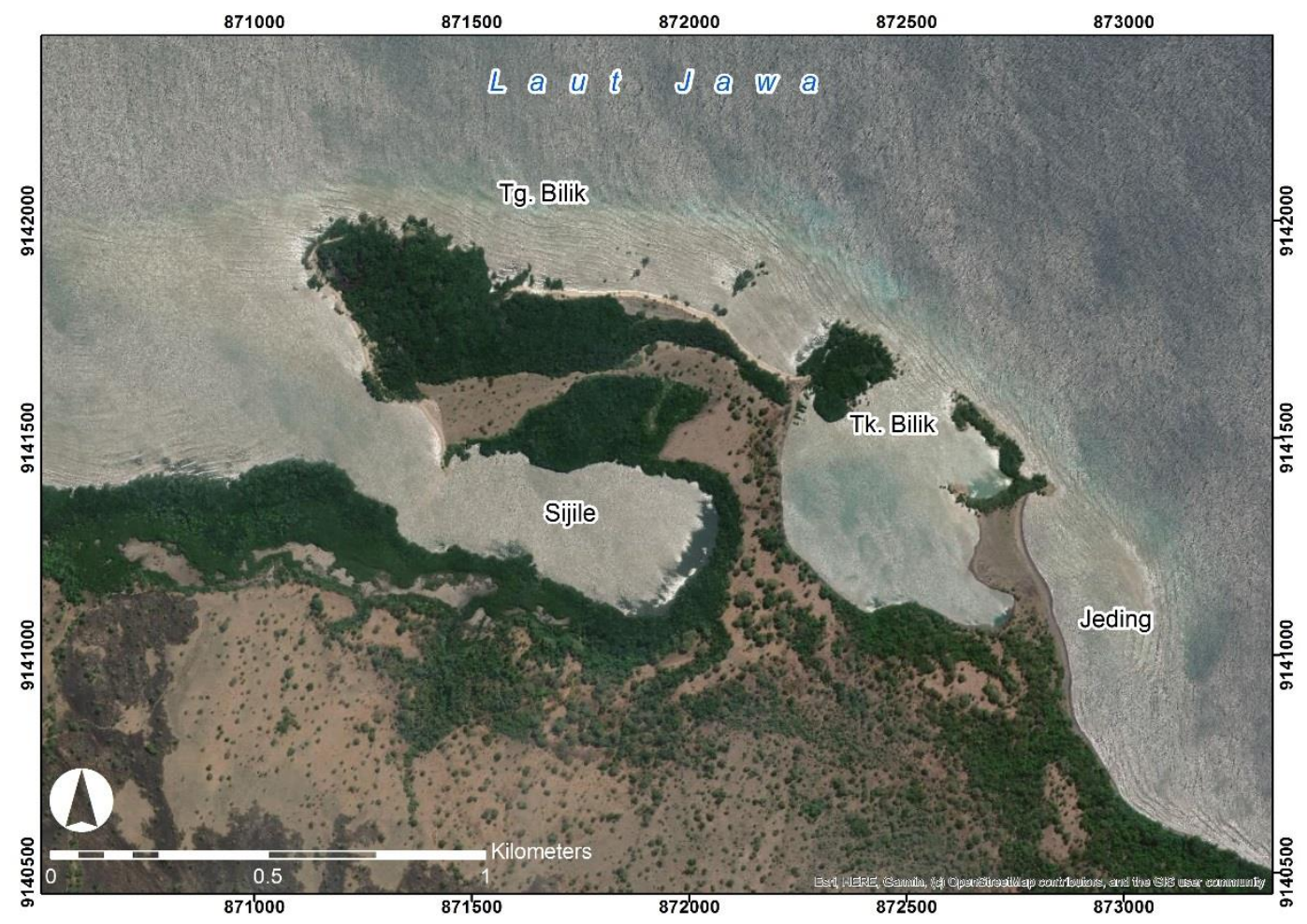

Gambar 2. Peta blok pengelolaan wilayah di Perairan Bilik, Taman Nasional Baluran

Adapun skema jalur transek dan visualisasi pengamatan megabentos dapat dilihat pada Gambar 3. Kelimpahan megabentos (X) dihitung menggunakan rumus Harvey (2008) seperti pada Persamaan (1).

$$
X=\frac{\text { Jumlah Individu }}{\text { Luas Garis Transek }\left(m^{2}\right)}
$$

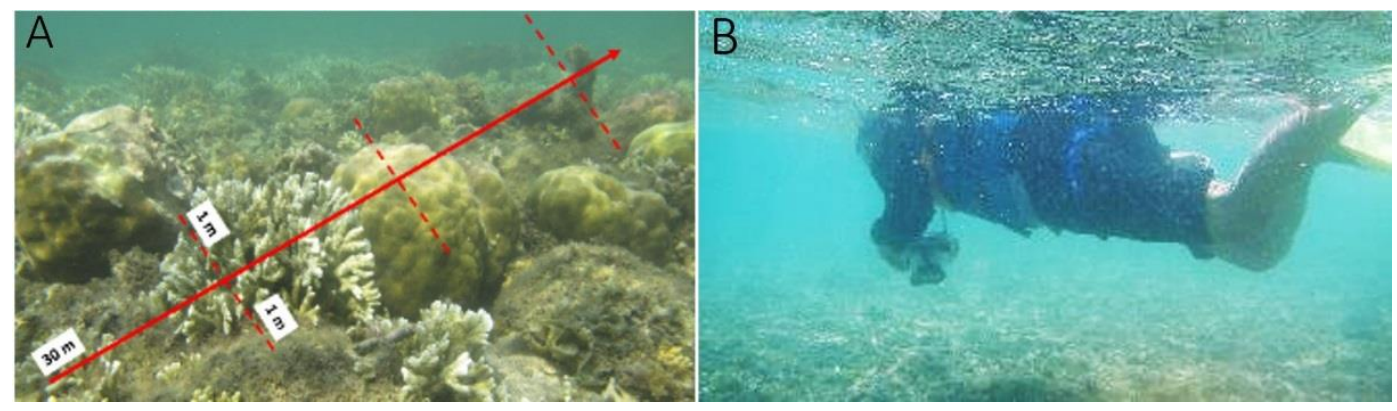

Gambar 3. (A) Skema garis transek (B) Teknik video bawah air (Courtesy: I.N. Rachmi, 2019)

Data kelimpahan megabentos dan hasil pemetaan ekosistem perairan di Perairan Bilik akan dianalisis menggunakan Sistem Informasi 
Geografi (SIG) dan analisis deskriptif. Analisis dilakukan dengan menggunakan pendekatan keruangan karena memberikan keunggulan untuk dapat melihat visualisasi sebaran kelimpahan megabentos di Perairan Bilik berdasarkan jalur transek yang telah dibuat. Setelah penyajian secara spasial dilakukan, maka analisis dilakukan secara deskriptif yaitu dengan mendeskripsikan kondisi lapangan berdasarkan data yang telah diperoleh.

\section{HASIL DAN PEMBAHASAN}

\section{Kelimpahan Megabentos di Perairan Bilik, Taman Nasional Baluran}

Perairan Bilik terdiri atas beberapa blok, yaitu Blok Jeding, Blok Tanjung Bilik, dan Blok Sijile. Menurut Giyanto dkk. (2014), spesies megabentos di perairan antara lain teripang, kima, lobster, lola, bintang laut berduri, siput drupella, bulu babi, dan bintang laut biru. Hasil pengamatan terumbu karang pada Perairan Bilik Blok Sijile dengan jarak hingga 50 meter dari garis pantai tidak ditemukan ekosistem terumbu karang melainkan hanya material berupa pasir, lumpur, dan pecahan karang. Tidak adanya terumbu karang yang terdapat di Perairan Bilik Blok Sijile berpengaruh terhadap keterdapatan megabentos yang sangat jarang ditemui dan jenis yang tidak bervariasi bahkan beberapa yang ditemui telah mati. Hal itu dikarenakan keberadaan setiap spesies atau kelompok spesies megabentos tidak lepas dari kondisi kesehatan terumbu karang sebagai habitat dari berbagai jenis fauna megabentos (Siringoringo $d k k$., 2014). Salah satu contoh megabentos yang mati ditunjukkan pada Gambar 4.

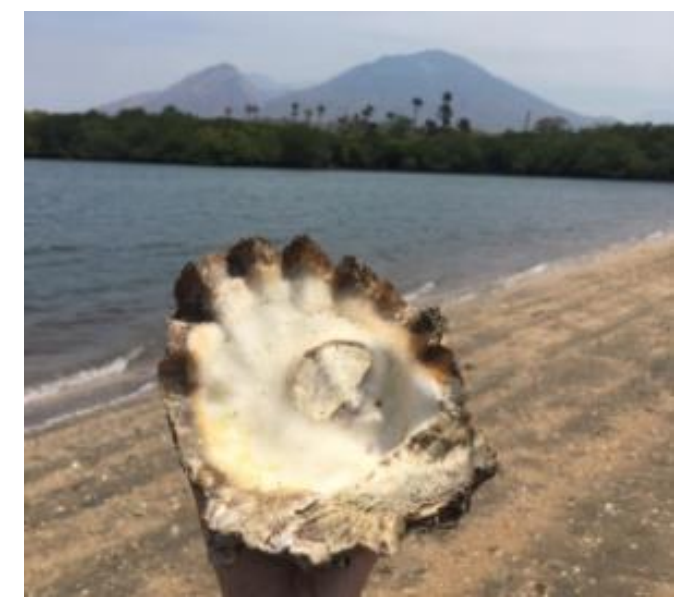

Gambar 4. Salah satu jenis megabentos (kima) yang telah mati di Blok Sijile, Perairan Bilik (Courtesy: S.I. Damayanti, 2019)

Pengamatan megabentos di Blok Jeding dilakukan dengan membuat jalur transek seperti yang terlihat pada Gambar 5. Blok Jeding memiliki kedalaman yang bervariasi mulai $<1$ meter hingga $>3$ meter memiliki jenis terumbu karang yang beragam serta kondisi perairan yang jernih. Kondisi 
tersebut juga berpengaruh terhadap kelimpahan megabentosnya. Kehadiran megabentos di ekosistem terumbu karang seringkali menjadi indikator bahwa karang di lokasi tersebut masih sehat, atau walaupun karang telah mengalami kerusakan, kondisi fisika-kimia perairan tersebut cukup mendukung kehidupan kelompok spesies megabentos tersebut (Siringoringo $d k k ., 2014$ ).

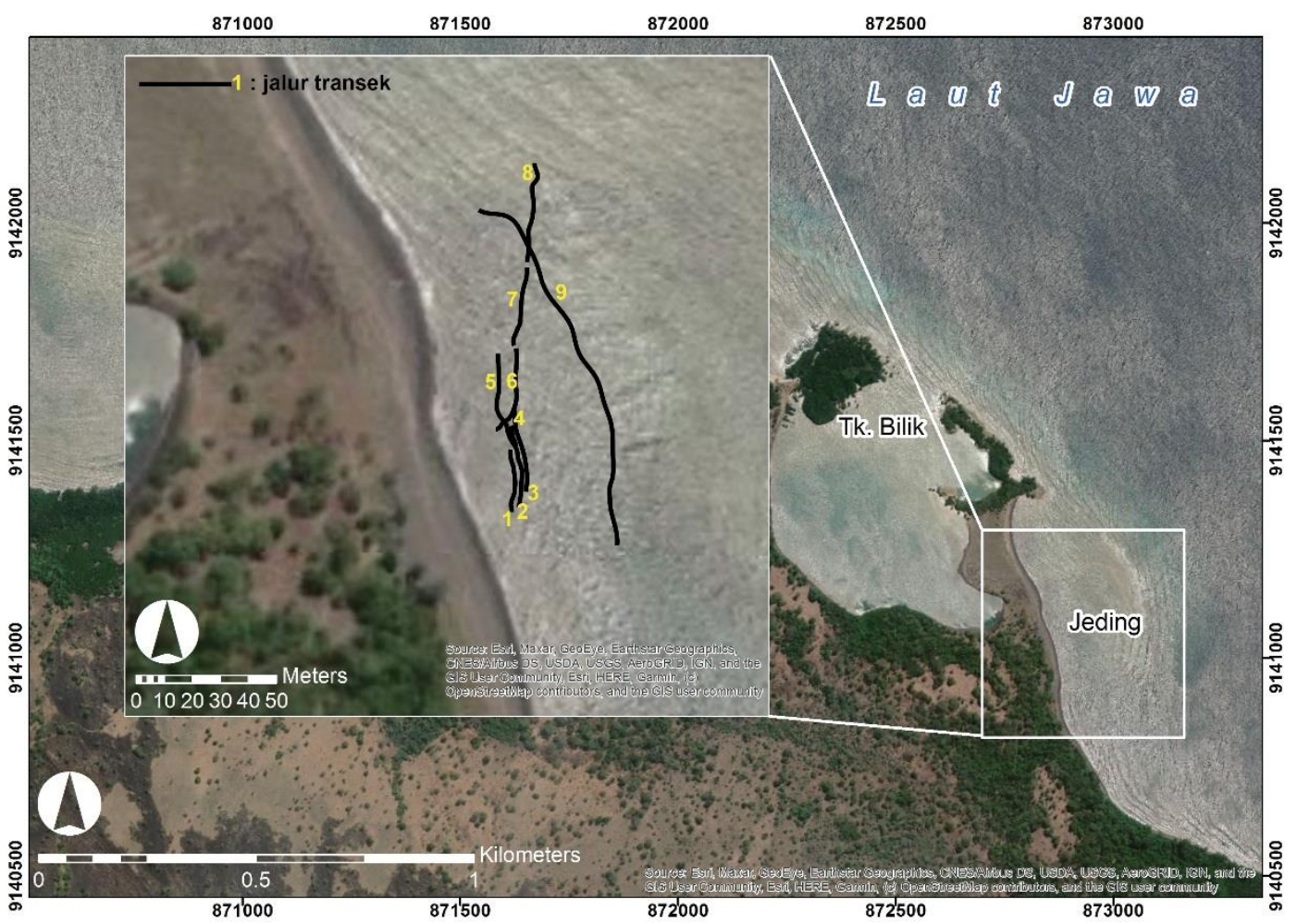

Gambar 5. Peta transek megabentos di Blok Jeding

Secara umum, spesies megabentos yang di temukan di jalur transek yang telah dibuat (Lihat Gambar 5) adalah bulu babi dan bintang laut biru. Megabentos tidak ditemukan pada jalur transek 3, 4, dan 5 yang masih terdapat beberapa terumbu karang, padahal menurut Hartati dkk. (2018) bulu babi dan bintang laut biru membutuhkan terumbu karang sebagai tempat tinggal karena terumbu karang menyediakan makanan berupa alga dan organisme yang juga hidup di ekosistem terumbu karang. Kelimpahan megabentos diperoleh melalui perhitungan dengan rumus Harvey (Persamaan 1), yaitu perbandingan jumlah individu megabentos dengan luas wilayah transeknya. Hasil identifikasi kelimpahan megabentos dapat dilihat pada Tabel 1.

Hasil pengamatan menunjukkan minimnya keberadaan megabentos di jalur transek 1-7. Pada jalur transek 8 dan 9 yang berada sedikit lebih jauh dari garis pantai, terdapat banyak terumbu karang dengan berbagai jenis, bulu babi, dan bintang laut biru. Suryanti dan Ruswahyuni (2014) menyebutkan bahwa bulu babi menyukai substrat yang keras untuk hidup, seperti terumbu karang, pecahan karang, dan lamun. Selain itu, bulu babi aktif di malam hari untuk mencari makan dan kembali bersembunyi di 
terumbu karang pada siang hari (Barnes, 1980). Pengambilan data pada penelitian ini dilakukan pada siang hari, sehingga bulu babi banyak ditemukan bersembunyi di sela-sela terumbu karang (Gambar 6).

Tabel 1. Identifikasi kelimpahan megabentos di Blok Jeding, Perairan Bilik

\begin{tabular}{cccccc}
\hline $\begin{array}{c}\text { Jalur } \\
\text { Transek }\end{array}$ & $\begin{array}{c}\text { Jumlah } \\
\text { Bulu } \\
\text { Babi }\end{array}$ & $\begin{array}{c}\text { Jumlah } \\
\text { Bintang } \\
\text { Laut Biru }\end{array}$ & Total & $\begin{array}{c}\text { Luas Area } \\
\text { Transek }\left(\mathbf{m}^{2}\right)\end{array}$ & $\begin{array}{c}\text { Kelimpahan } \\
\left.\text { (Individu/m }{ }^{2}\right)\end{array}$ \\
\hline 1 & 0 & 1 & 1 & 51,00 & 0,02 \\
2 & 0 & 1 & 1 & 42,80 & 0,02 \\
$3,4,5$ & 0 & 0 & 0 & 175,00 & 0,00 \\
6 & 0 & 3 & 3 & 66,40 & 0,04 \\
7 & 2 & 0 & 2 & 53,40 & 0,04 \\
8 & 1 & 0 & 1 & 75,40 & 0,01 \\
9 & 28 & 8 & 36 & 266,00 & 0,14 \\
\hline
\end{tabular}
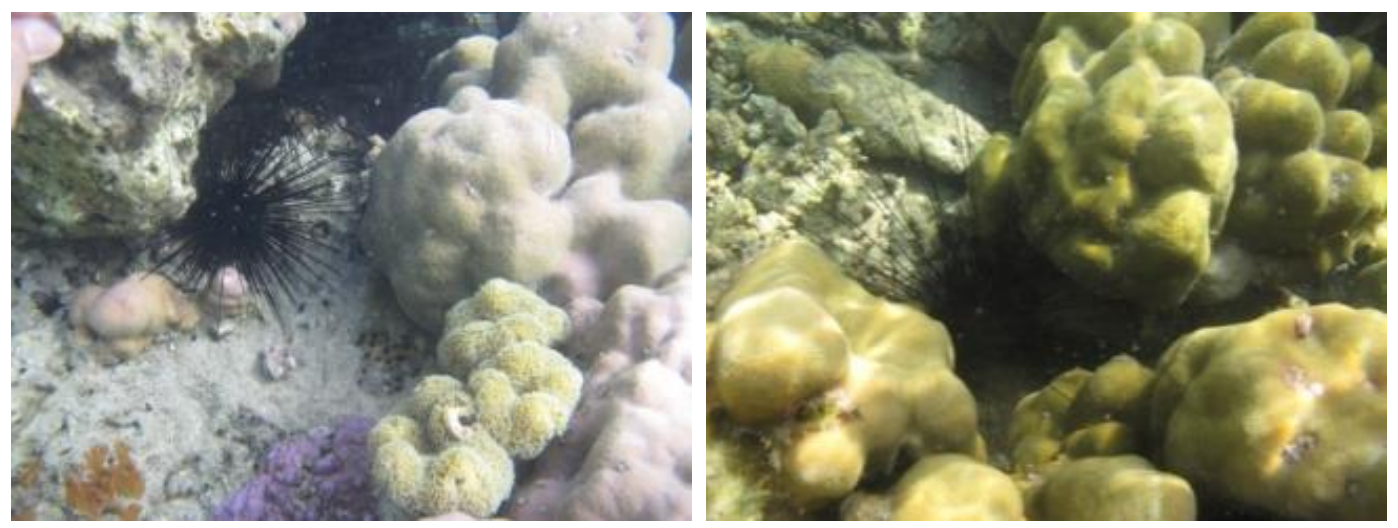

Gambar 6. Bulu babi yang ditemukan di Blok Jeding, Perairan Bilik (Courtesy: B. Aditya, 2019)

Menurut Satyawan dan Atriningrum (2019), pergerakan dari kelompok organisme megabentos ini cenderung sangat terbatas dan relatif menetap pada substrat-substrat sehingga menjadi lebih sensitif terhadap lingkungan perairan. Salah satu megabentos yang ditemukan di lokasi penelitian yaitu bulu babi. Bulu babi dapat hidup secara mengelompok (besar maupun kecil) dan menyendiri (Suryanti dan Ruswahyuni, 2014). Oleh karena itu, pada jalur transek 8 hanya ditemukan 1 bulu babi. Berbeda dengan jalur transek 9 yang merupakan jalur terpanjang terdapat total 28 bulu babi yang hidup secara berkelompok dan 8 bintang laut biru, sehingga hasil perhitungan megabentos di jalur ini menjadi yang tertinggi yaitu 0,14 individu/m².

Keberadaan bulu babi dan bintang laut biru secara umum tidak membahayakan ekosistem terumbu karang, lain halnya dengan alga. Alga merupakan ancaman bagi kehidupan terumbu karang dikarenakan alga akan menyerang terumbu karang yang terkena penyakit. Penyakit tersebut dapat berasal dari faktor alam dan lingkungan, sehingga apabila 
alga menyerang terumbu karang yang terkena penyakit, maka terumbu karang tersebut tidak dapat melakukan pemulihan dengan sempurna (Zamani, 2015). Suryanti $d k k$. (2018) menjelaskan bahwa makro alga tersebut merupakan pesaing bagi terumbu karang untuk mempertahankan ruang bertahan hidup, terutama sinar matahari. Tidak adanya bulu babi sebagai pemakan alga secara tidak langsung akan menyebabkan peningkatan jumlah makro alga serta mengakibatkan penutupan ruang hidup terumbu karang.

Keberadaan alga yang merugikan terumbu karang tersebut dapat dihalau oleh bulu babi dan bintang laut biru, karena kedua biota tersebut memiliki peran sebagai grazer (pemakan alga) di dalam ekosistem terumbu karang. Populasi bulu babi sebagai grazer ini sangat penting untuk menjaga komunitas alga dalam biomassa rendah (Cerpenter, 1985), menjaga kesehatan terumbu karang dengan memakan alga, dan meninggalkan substrat bersih supaya larva karang baru dapat menetap (Ruiz-Ramos dkk., 2011). Aktivitas grazer yang dilakukan oleh bulu babi bahkan mampu menghilangkan kanopi alga dan/atau mencegah pemulihannya serta dapat menyediakan dan memelihara substrat tempat organisme lain untuk dapat menetap dan bertahan hidup (Coma $d k k$, 2011). Tyrell (2014) dalam penelitiannya menjelaskan hubungan antara kelimpahan bulu babi dan makro alga menunjukkan korelasi negatif, artinya bahwa peningkatan kepadatan bulu babi akan menghasilkan pengurangan tutupan makro alga. Sementara menurut McClanahan dan Saphir (1990), tutupan karang dan kompleksitas topografi berkorelasi negatif dengan kepadatan total bulu babi.

Selain grazer, bintang laut biru juga merupakan predator pemakan organisme yang hidup di sekitar terumbu karang seperti keong. Menurut Zamani (2015), bintang laut biru berbeda dengan bintang laut jenis mahkota duri, karena bintang laut biru tidak memakan polip karang, sehingga tidak membahayakan kehidupan karang (Gambar 7). Peran penting lainnya adalah bintang laut biru merupakan pemakan detritus (sisa-sisa organisme lain). Dari sifat makan ini, bintang laut biru berperan dalam menjernihkan laut sehingga kualitas perairan menjadi lebih baik.

Perubahan yang terjadi pada kondisi dan substrat terumbu karang akan memicu komposisi megabentos sehingga sering digunakan sebagai bio-indikator untuk memantau kondisi ekosistem terumbu karang (Satyawan dan Atriningrum, 2019). Jumlah individu bulu babi yang diperoleh pada setiap garis transek yang berbeda juga dipengaruhi oleh kondisi substrat dan ketersediaan alga sebagai makanan, terutama untuk bulu babi. Oleh karena itu, kehadiran bulu babi dalam jumlah yang besar mengindikasikan bahwa terumbu karang tidak sehat karena bulu babi memangsa alga yang tumbuh pada karang, sehingga memungkinkan karang memiliki kesempatan pemulihan lebih tinggi (Abrar, 2015) (Gambar 8). 



Gambar 7. (A) bintang laut mahkota duri pemakan polip karang (Courtesy: Jalaluddin \& Ardeslan, 2017) dan (B) bintang laut biru (Courtesy: I.N. Rachmi, 2019)
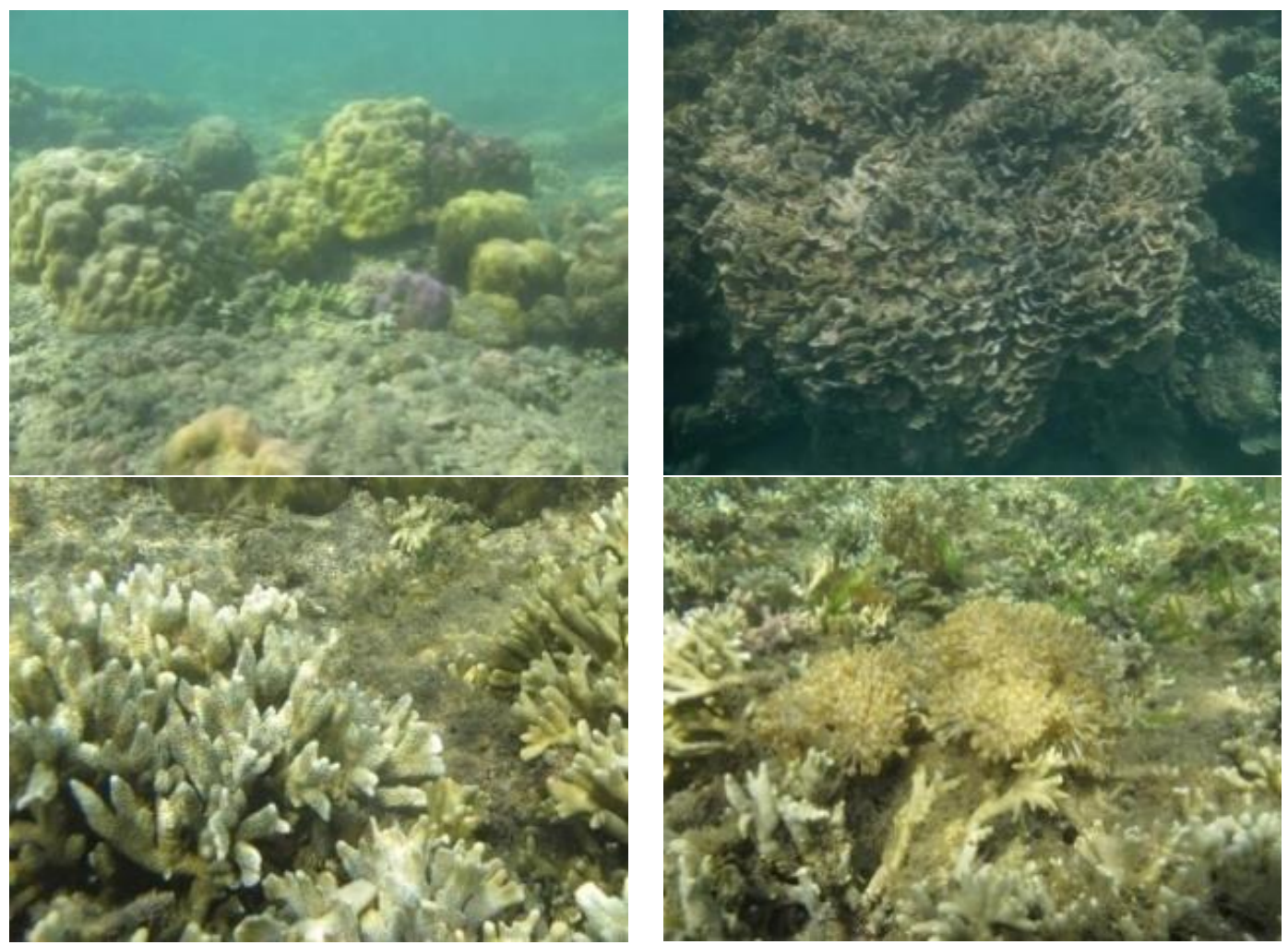

Gambar 8. Beberapa contoh kondisi terumbu karang di Blok Jeding, Perairan Bilik (Courtesy: I.N. Rachmi, 2019)

\section{KESIMPULAN}

Megabentos hanya ditemukan pada Blok Jeding yaitu berupa bulu babi dan bintang laut biru dalam jumlah yang sedikit. Hal ini mengindikasikan bahwa kualitas ekosistem terumbu karang di perairan ini masih baik, sebab keberadaan megabentos yang berlebihan mengindikasikan bahwa ekosistem terumbu karang buruk. Kondisi faktual juga masih menunjukkan bahwa kualitas ekosistem masih baik, namun beberapa area memang telah mengalami kerusakan akibat pemutihan karang dan aktivitas perikanan yang tidak ramah lingkungan. Tantangan utama dalam kelestarian ekosistem terumbu karang di Perairan Bilik 
adalah peningkatan pengetahuan nelayan serta pemanasan global. Oleh karena itu, diperlukan usaha restorasi terumbu oleh pihak pengelola Taman Nasional Baluran agar kelestarian terumbu karang terjaga dan dapat dikembangkan sebagai wisata berkelanjutan.

\section{UCAPAN TERIMA KASIH}

Penelitian ini merupakan bagian dari Kuliah Kerja Lapangan 3 di Departemen Geografi Lingkungan, Fakultas Geografi Universitas Gadjah Mada. Penulis mendedikasikan artikel ini kepada almarhum Prof. Sunarto. Akhirnya, penulis menyampaikan terima kasih kepada reviewer atas komentar dan masukkan yang membangun untuk perbaikan artikel ini.

\section{DAFTAR PUSTAKA}

Abrar, M. 2015. Monitoring Kesehatan Terumbu Karang dan Ekosistem Terkait di Taman Wisata Perairan (TWP) Selat Bunga Laut, Kabupaten Kepulauan Mentawai, Sumatera Barat. Jakarta: COREMAP CTI - LIPI.

Arjasakusuma S., Mutaqin B.W., Sekaranom A.B., Marfai M.A. 2020. Sensitivity of Remote Sensing-based Vegetation Proxies to Climate and Sea Surface Temperature Variabilities in Australia and Parts of Southeast Asia. International Journal of Remote Sensing. https://doi.org/10.1080/01431161.2020.1782509.

Barnes, R.D. 1980. Invertebrate Zoology 4th edition. Holt Saunders International, Philadelphia and Tokyo.

Cerpenter, R.C. 1985. Sea Urchin Mass-Mortality: Effects On Reef Algal Abundance, Species Composition, and Metabolism and Other Coral Reef Herbivores. Proc. Fifth Inter. Coral Reef Congress, Tahiti 4:5360 .

Chumkiew, S., Jaroensutasinee, K., dan Jaroensutasinee M. 2011. Impact of Global Warming on Coral Reef. Walailak Journal of Science and Technology, Nomor 8 Volume 2.

Coma R, Serrano E, Linares C, Ribes M, Díaz D, Ballesteros E 2011 Sea Urchins Predation Facilitates Coral Invasion in a Marine Reserve. PLoS ONE 6(7): e22017. https://doi.org/10.1371/journal.pone.0022017.

Giyanto, Manuputty, A. E., Abrar, M., M, R., Siringoringo, R.Suharti, S., ... Zulfianita, D. 2014. Panduan Monitoring Kesehatan Terumbu Karang. Jakarta: Pusat Penelitian Oseanografi Lembaga IImu Pengetahuan Indonesia. 
Hartati, R., Meirawati, E., Redjeki, S., Riniatsih, I., \& Mahendrajaya, R. 2018. Jenis-Jenis Bintang Laut dan Bulu Babi (Asteroidea Echinodea: Echinodermata) di Perairan Pulau Cilik, Kepulauan Karimunjawa. Jurnal Kelautan Tropis, vol. 21, no. 1, pp. 41-48, Apr. 2018. https://doi.org/10.14710/jkt.v21i1.2417.

Harvey, J.T. 2008 Abundance. Encyclopedia of Ecology (ed. by S.E.J. Fath and D. Brian), pp. 4-10. Academic Press, Oxford.

Jalaluddin dan Ardeslan. 2017. Identifikasi dan Klasifikasi Phylum Echinodermata di Perairan Laut Desa Sembilan Kecamatan Simeulue Barat Kabupaten Simeulue. Jurnal Biology Education, 6(2), http://dx.doi.org/10.32672/ibe.v6i2.435.

Lukman, Chrismandha, T., Fakhrudin, M., \& Sudarso, J. 2009. Komunitas Biota Hewan Bentik Pada Danau Paparan Banjir Di Kalimantan Timur. Biosfera, 26(3), 115-123. https://doi.org/10.20884/1.mib.2009.26.3.164.

McClanahan, T. R., dan S. H. Shafir. 1990. Causes and consequences of sea urchin abundance and diversity in Kenyan coral reef lagoons. Oecologia 83:362-370. https://doi.org/10.1007/BF00317561.

Muhlis. 2011. Ekosistem Terumbu Karang dan Kondisi Oseanografi Perairan Kawasan Wisata Bahari Lombok. Berkala Penelitian Hayati, 16(2), 111-118.

Mutaqin B.W. dan Angga B.R.D. 2013. Analisa Spasial Sebaran Suhu Permukaan Laut Di Perairan Jepara Menggunakan Citra Landsat 8. Prosiding Simposium Nasional Sains Geoinformasi 2013, 25 - 26 September 2013, Yogyakarta, Indonesia.

Mutaqin B.W. dan Rohmah F.N. 2013. Biodegradation of Seagrass Ecosystem and its Implication on Coastal Resources in Maratua Island, East Kalimantan - Indonesia. Proceeding in Ecosystem Disaster Risk Reduction. Master Program in Planning and Management of Coastal Area and Watershed in cooperation with Center for Natural Resources and Development (CNRD). ISBN: 978602-14856-1-5.

Mutaqin B.W. 2017. Shoreline Changes Analysis in Kuwaru Coastal Area, Yogyakarta, Indonesia: An Application of the Digital Shoreline Analysis System (DSAS). International Journal of Sustainable Development and Planning 12(7), pp. 1203-1214. https://doi.org/10.2495/SDP-V12-N7-1203-1214. 
Mutaqin B.W., Lavigne F., Landa A., Ahyadi H., Hadmoko D.S., Hananto N., Handayani L., 2018. The Impact of AD 1257 Samalas Eruption to Coral Reef Ecosystems on the East of Lombok, Indonesia, Asia Oceania Geosciences Society (AOGS) 15th Annual Meeting, 3 - 8 June 2018, Honolulu, Hawaii.

Mutaqin B.W., Marfai M.A., Helmi M., Rindarjono M.G., Windayati R., Sunarto 2020. Spatio-temporal Mapping of Ecotourism Activities in Buleleng Conservation Zone: A Methodological Review, IOP Conf. Ser.: Earth Environ. Sci. 451 012095. https://doi.org/10.1088/17551315/451/1/012095.

Nurrohmah, I. 2018. Kepadatan dan Pola Distribusi Populasi Anadara antiquata L. di Zona Interdal Pantai Bilik Taman Nasional Baluran. Skripsi. Universitas Jember.

Peraturan Menteri Kehutanan Republik Indonesia Nomor P4/MENHUTII/2012, Tentang perubahan atas peraturan Menteri Kehutanan Nomor P.48/MENHUT-II/2010 Tentang Pengusahaan Pariwisata Alam di Suaka Margasatwa, Taman Nasional, Taman Hutan Raya dan Taman Wisata Alam.

Ruiz-Ramos, Dannise V; Hernández-Delgado, Edwin A; Schizas, Nikolaos V. 2011. Population status of the long-spined urchin Diadema antillarum in Puerto Rico 20 years after a mass mortality event. Bulletin of Marine Science, Volume 87, Number 1, January 2011, pp. 113-127(15). https://doi.org/10.5343/bms.2010.1038.

Satyawan, N. M. Dan Atriningrum, N. T. 2019. Kondisi Eksisting Fauna Megabenthos di Perairan Labuhan Pandan Lombok Timur Pasca Gempa Bumi Lombok 7.0 Skala Ritcher. Jurnal Biologi Tropis. 19(2): 172-179. http://dx.doi.org/10.29303/jbt.v19i2.1303.

Siringoringo, Rikoh M., Rizkie Satria, M. Abrar, Bambang H, Kunto W, Ucu Arbi, Mudjiono, Wayan Eka, Susi R, dan R. Sutiadi. 2014. Monitoring Kesehatan Terumbu Karang dan Kesehatan Ekosistem terkait di Kabupaten Kepulauan Mentawai. Jakarta: Lembaga IImu Pengetahuan Indonesia.

Sohilait, I. M. 2006. Kualitas Perairan Pesisir Teluk Ambon Dalam Berdasarkan Keanekaragaman Makrozoobentos sebagai Bioindikator. Tesis. Ilmu Lingkungan. Universitas Gadjah Mada, Yogyakarta.

Sunarto, Malawani M.N., Mutaqin B.W. 2019. Geomorfologi Lingkungan Pesisir. Badan Penerbit Fakultas Geografi: Yogyakarta. p160. 
Suryanti dan Ruswahyuni. 2014. Perbedaan Kelimpahan Bulu Babi(Echinoidea) pada Ekosistem Karang dan Lamun di Pancuran Belakang, Karimunjawa Jepara. Jurnal Saintek Perikanan. Vol. 10(1): 62-67.

Suryanti, S., Churun A., dan Nurul A. 2018. Relationship Between of Sea Urchin Abudance, Macroalgae and Coral Closure on the Cemara Kecil Island. J. Phys.: Conf. Ser. 1025012038. https://doi.org/10.1088/1742-6596/1025/1/012038.

Tyrrell, S. 2014. The Distribution and Impact of Sea Urchins on Coral Reefs in Watamu, Kenya. Dissertation. Faculty of Geography. University of Exeter.

Zamani, N.P. 2015. Kondisi Terumbu Karang dan Asosiasinya dengan Bintang Laut (Linckia Laevigata) di Perairan Pulau Tunda, Kabupaten Seram, Provinsi Banten. Jurnal Teknologi Perikanan dan Kelautan Vol. 6 No. 1 Mei 2015: 1-10. https://doi.org/10.24319/jtpk.6.1-10.

Zulkifli, H., \& Setiawan, D. 2012. Struktur Komunitas Makrozoobentos di Perairan Sungai Musi Kawasan Pulokerto sebagai Instrumen Biomonitoring. Jurnal Natur Indonesia, 14(01), 95-99. https://doi.org/10.31258/jnat.14.1.95-99. 